\title{
CASP10 wt Allele
}

National Cancer Institute

\section{Source}

National Cancer Institute. CASP10 wt Allele. NCI Thesaurus. Code C49547.

Human CASP10 wild-type allele is located within 2q33-q34 and is approximately $46 \mathrm{~kb}$ in length. This allele, which encodes caspase-10 protein, plays a role in the activation of caspase-dependent apoptosis. Defects in the CASP10 gene are the cause of type II autoimmune lymphoproliferative syndrome. 